\title{
Why Don't Docs Digitize? The Adoption of Health Information Technology in Primary Care Medicine
}

\author{
Adam Seth Litwin* \\ Carey Business School \\ Johns Hopkins University
}

May 11, 2009

\begin{abstract}
Reformers in the US have earmarked substantial resources towards encouraging the adoption of electronic health records (EHRs). However, studies have yet to explain why physicians resist adoption and why the investments resulting from a policy push may prove ineffective for improving the efficiency of healthcare delivery. I theorize that health information technology (IT) facilitates certain outcomes that bolster industry-level efficiency, but that the conventional, "fee-for-service" financing of primary care prevents many physicians from appropriating these benefits. Those physicians financing care delivery from a prepaid premium, on the other hand, are positioned to internalize what are otherwise external economies attendant to health IT investment. I find strong statistical support for this theory in a unique panel of US-practicing primary care physicians that allows us to examine health IT adoption as far back as 2001-long before it garnered policymakers' attention. The results imply that reformers should focus not on encouraging health IT adoption per se, but on reforms that enable physicians to internalize what are presently socialized benefits.
\end{abstract}

\section{Introduction}

The promise of health information technology (IT) for increasing the efficiency of healthcare delivery in the US has spurred a great deal of interest from policymakers, most recently in the form of the Health Information Technology for Economic and

*Thank you to seminar participants at the Johns Hopkins Bloomberg School of Public Health and the Johns Hopkins Carey Business School as well as to Maqbool Dada and Phillip Phan for comments and suggestions. 
Clinical Health (HITECH) Act - a $\$ 21.8$ billion carve-out of the Obama administration's economic stimulus package. Reformers justify the allocation of these resources by blaming the slow diffusion of health IT for the poor performance of the healthcare industry, marked by skyrocketing costs, high rates of medical errors, high infant mortality, and below average life expectancies (Kaiser Family Foundation 2007). The administration, citing a RAND Corporation study (Hillestad et al. 2005), points to a projected annual savings of $\$ 81$ billion from the effective deployment of health IT systems. In short, policymakers believe that physicians will use health IT to provide higher-quality care at lower costs. Therefore, they have embarked on an effort to spur adoption through a series of incentive payments for those doctors reaching certain targets for adoption and so-called "meaningful use." By taking a closer look at which doctors have already adopted health IT, this study suggests that policies that make physicians beneficiaries of the effective deployment of the technology are preferred to policies that simply pay doctors back for buying and installing the technology.

This study critiques current health IT policy by examining the adoption patterns of a panel of US-practicing, primary care physicians (PCPs). The choice to restrict the analysis to PCPs has both substantive and methodological justifications. From the reformer's perspective, the dearth of health IT investment is especially acute in the non-hospital or "ambulatory" environment - medical offices - the organizational settings from which patients seek primary care (DesRoches et al. 2008). This interests researchers and policymakers since most office visits are to primary care providers, not specialists. With respect to theory, the integrative nature of primary care makes it the locus for many of the efficiency gains expected to arise from health IT. Finally, health IT may need to be tailored or reconfigured especially for smaller-niche, specialist settings (Bates 2005). Therefore, from an empirical perspective, a constrained focus on primary care eliminates unobserved sources of variation in the drivers of health IT adoption.

PCPs access health IT through their medical practices. Some physicians report access to the technology at least as far back as 2001. I argue that these "early adopters" did so because they were affiliated with those few medical practices that could actually internalize what would otherwise be inappropriable, social returns to health IT investments. This implies that there may be a less expensive way to encourage adoption than by paying doctors to do so. Add to this our understanding of what is required to establish a connection between IT investment and performance, namely a set of concomitant investments in training and work redesign (Bresnahan, Brynjolfsson, and Hitt 2002, Brynjolfsson, Hitt, and Yang 2002), and the findings indicate 
that current policies are misdirected. This study instead calls for a policy framework that makes more physicians and their practices beneficiaries of the effective use of IT, encouraging adoption of the technology and its organizational complements by those physicians most likely to leverage it effectively. In this way, it informs a very active area for policymakers while contributing an economics-oriented perspective to the small set of existing studies of health IT diffusion.

This paper is organized as follows. Section II considers health IT's benefits and theorizes drivers of health IT investment. Section III provides empirical evidence in support of the theory. The final section concludes by discussing the implications of the estimates and by suggesting appropriate areas for follow-up study.

\section{Background and Framework for Analysis}

Health IT is the label applied to those IT applications employed in the healthcare context whether the information being processed is clinical, financial, or administrative in nature (Bower 2005). These applications frequently serve as components of an electronic health record (EHR) system; however, an EHR system implies a high level of inter-functional integration, interoperability, and coordination between individual components of health IT. It is actually EHRs, not health IT per se, that are expected to improve the performance of the healthcare industry. Nonetheless, the adoption of health IT can be measured reliably and is a prerequisite to deploying more comprehensive EHR systems.

There are a number of reasons why policymakers might suspect a link between the deployment of health IT and improved performance. For starters, the sector appears to have opted out of the IT "revolution" that swept most other industries in the US and brought measurable performance improvements in tow (Jorgenson and Stiroh 1999, Oliner and Sichel 2000, Porter and Teisberg 2006). Reformers might also be looking to healthcare systems internationally, which seem to be achieving better outcomes at lower costs while demonstrating that they are further down the health IT adoption path (Schoen et al. 2006). Indeed, to the extent health IT crosses patient- and context-specific data with current information on best practices, it could be part of the solution to many of healthcare's apparent inefficiencies. For example, physicians could leverage context-sensitive best practice alerts toward the prevention or escalation of chronic diseases, the treatment costs of which account for over 80 percent of the nation's annual healthcare bill (Anderson and Knickman 2001). According to one account, "solid medical science" makes clear, for example, that 
for those who have suffered a heart attack, the administration of inexpensive beta blockers would reduce their likelihood of a second heart attack by more than 40 percent. However, only about 60 percent of those that should be on beta blockers actually are (Halvorson and Isham 2003). Even when providers are aware of best practices, they lack the requisite information to seek-out at-risk patients and to deliver preventive treatment. As a result, best practice compliance rates sit at just 55 percent (McGlynn et al. 2003). Finally, significant savings accrue from reductions in the "utilization of care" (Chaudhry et al. 2006). That is, the adoption of health IT reduces demand for unnecessary or duplicative diagnostic and laboratory services (Garrido et al. 2005). It also allows for the substitution of lower-cost telephone and secure messaging encounters for more costly, in-person office visits (Zhou et al. 2007).

In short, one might expect health IT to improve patient health as well as the allocation of physician-provided care. In this way, doctors' use of health IT could improve the overall, economic efficiency of the industry. Nonetheless, the diffusion of non-hospital health IT generally hovers below 20 percent, particularly for comprehensive and integrated health IT systems (e.g., Burt and Sisk 2005, DesRoches et al. 2008). An analysis of physicians' reported access to the technology reveals a connection between the technology's anticipated benefits and its adoption, a link that can be explained in the context of Griliches's (1957) seminal work on the diffusion of new technologies. Hybrid corn, the focal innovation in Griliches's analysis, proved superior in a number of ways to conventional, "open-pollination" seed, yet many farmers continued using the inferior product for many years after the first appearance of the new technology. He used government data to establish the notion of "expected profitability" as a driver of technology adoption, a theory further formalized by Mansfield (1961) and incorporated into diffusion studies of many other technologies including industrial automation (Mansfield 1989) and automated teller machines (ATMs) (Saloner and Shepard 1995). This subsequent empirical work focused on adopter heterogeneity as a driver of adoption patterns. While this construct understandably differs by context, Hall and Khan (2003) underline the need to examine the benefits received and the costs incurred by the would-be adopter as key determinants of adoption behavior. Applying this line of thought to the adoption context surrounding health IT clarifies the reasons for slow diffusion. It also suggests the type of policies that could hasten not only adoption of the technology itself, but the realization of the efficiency goals intended of the technology. In the case of health IT, structural characteristics of the industry drive a wedge between the benefits of health IT as seen by physicians and the benefits perceived by policymakers 
considering society-at-large.

\section{A. Benefits of Health IT to Physicians}

Summing across the avenues by which health IT could help physicians keep patients healthy, one can begin to envisage the sizable efficiency gains anticipated by policymakers. However, just how these benefits are partitioned influences adoption patterns. In the case of hybrid corn, industrial robots, or ATMs, the investing farmer, factory, or bank, respectively, expected to recoup the returns on the investment, net of the benefits captured by other parties such as workers or customers. This is not necessarily the case with primary care medicine. Who benefits from adopting health IT depends on how the healthcare being provided is actually financed.

Suppose the marginal cost of health IT to physician $i$ is $C_{i}$, that total benefits are represented by $V$, and that the share of benefits accruing to the investing physician is represented by $\phi_{i}$ such that $0 \leq \phi_{i} \leq 1$. Then the total value arising from a physician's investment in health IT is represented by

$$
C_{i}=\phi_{i} V+\left(1-\phi_{i}\right) V
$$

If, in fact, the investing physician's practice could internalize all of the benefits arising from the technology, then $\phi_{i}=1$, and the second term drops out of Equation 1 entirely. On the other hand, if $\phi_{i}<1$, then the second term drives a wedge between marginal benefits and marginal costs. Therefore, the physician will only invest in health IT up to the point at which $C_{i}=\phi_{i} V$, yielding an equilibrium level of health IT investment that is systematically and strictly less than would be the case in the absence of external economies - conceptualized as $\left(1-\phi_{i}\right) V$.

\section{B. Healthcare Financing Model}

There is good reason to suspect that $\hat{\phi}<1$. Many of the benefits believed to arise from health IT investments accrue to someone other than the physician or her medical practice. ${ }^{1}$ One critical determinant of whether or not physicians benefit from health IT investment is the model under which their medical practice finances the care it delivers - fee-for-service (FFS) or prepaid. Under the conventional, FFS model, medical practice organizations deliver patient care by contracting with multiple health plans that indemnify the provider on a claim-by-claim basis according

\footnotetext{
${ }^{1}$ Walker et al.'s (2005) study of the benefits of one particular form of health IT, computerized ordering, implies a value for $\hat{\phi}$ of approximately .11 .
} 
to pre-negotiated rules regarding which procedures are covered and at what rate the practice will be reimbursed (Cutler, McClellan, and Newhouse 2000). Organizations profit as residual claimants on each of these payments. Consequently, these practices benefit from providing the services of each claim as efficiently as possible and from generating as many reimbursable claims as possible, with an emphasis on those treatments that leave more claims revenue in excess of costs. Under the prepaid or "capitated" model, on the other hand, the medical practice internalizes the risk of its patient population, effectively assuming the role of health insurer in addition to its role as healthcare provider. It does this by charging a per-member, per-month premium from which it finances all required care. Under this model, practices profit as residual claimants on the monthly premium. ${ }^{2}$

Some of the returns to health IT investments accrue to physicians and their medical practices irrespective of the model under which they finance care, namely cost reductions associated with a reduced need to locate, retrieve, deliver, and refile paper charts as well as reduced demand for transcription services. There are even savings that accrue exclusively to those under the FFS model. For example, the use of computers could allow organizations to "capture" revenues from procedures that were performed, but undocumented in the course of an office visit (Wang et al. 2003), as well as from claimable procedures that the provider may have overlooked altogether (Walker et al. 2005). However, I argue that most of the benefits arising from health IT investments accrue only to practices operating under the prepaid model.

Health IT improves the coordination of care by providing physicians with information gathered by the patient's other providers as well as deep and rich historical data on the patient (Halvorson and Isham 2003) - information that may or may not be available in a conventional paper record, but would certainly require greater resources to locate. Along the same lines, IT-enabled advances promote best practices, including the substitution of cheaper preventive measures for much more costly treatment efforts. In all of these ways, the patient and society-at-large benefit from the health IT-engendered reallocation of healthcare resources. However, with respect to

\footnotetext{
${ }^{2}$ The capitated model can itself be divided into "sub-models" based on the structure linking the provision and insurance functions. In some cases, the physicians and support staff literally work for the same organization that markets health plans to groups or individuals in addition to employing doctors to care for patients. Other medical practices falling under the same financing model instead contract with one or more separate entities that market health plans. It follows that those physicians delivering care according to the latter arrangement do not work directly for a health insurer; however, because these medical practices finance care with a pre-negotiated, permember, per-month prepayment, doctors in this setting work for an organization that has assumed the role of health insurer, at least with respect to the internalization of risk.
} 
medical practices, only those financing care on a prepaid basis share in these benefits. And, only those practices expecting to appropriate these benefits should be expected to invest in these technologies. That is, physician $i$ 's anticipated value for $\phi$ will be greater when she is affiliated with a practice that finances care through the capitated model. Therefore, she will be more likely to adopt health IT than a similarly-situated physician financing care under the traditional model.

\section{Empirical Evidence}

I use data from the Community Tracking Study (CTS) to show that the financing model under which a physician's practice operates predicts his or her access to health IT. The CTS is administered by the Center for Studying Health System Change (2003, 2006) and sponsored by the Robert Wood Johnson Foundation. It allows us to measure health IT diffusion as far back as 2001, long before the start of the present policy push for EHR adoption. The 2001 and 2005 cross-sections include data from 8,665 distinct PCPs. Table 1 explains the construction of variables. The top half shows measures of health IT adoption. Each of seven IT applications - writing prescriptions (ITPRESC), communicating with patients (ITCOMM), researching treatment information and guidelines (ITTREAT), checking the contents of the formulary (ITFORM), generating reminders for preventative services (ITREMIND), accessing patient notes (ITNOTES), and exchanging clinical data and images with other physicians (ITCLIN) - is first measured independently with a binary variable equal to one for an affirmative response. I then sum affirmative responses to measure the intensity with which a physician's medical practice adopts IT, captured in the variable ITUSE.

[Table 1 about here.]

The rest of Table 1 outlines the construction of the independent variables. The variable PREPAID captures the financing model underpinning healthcare delivery at the respondent's medical practice. The use of a binary indicator based on a practice's designation as an Health Maintenance Organization (HMO) sets up a conservative test of the theory since it captures only those practices that finance all care on a prepaid basis. Of course, the healthcare financing model is of special, substantive importance here. As I will argue, the adoption encouraged by the prepaid model is the kind of adoption that puts the technology in the hands of the very physicians that can most benefit from its effective use and whose effective use helps to deliver the goals that policymakers intend for it. Nonetheless, there are other drivers of 
health IT adoption that must be controlled for in order to identify the adoption effects of the reimbursement model. First among these is the size of a physician's medical practice. Previous empirical examinations of the diffusion of health IT find that small medical practices are much less likely to embrace the technology than are larger ones (e.g., DesRoches et al. 2008, Gans et al. 2005). There are a number of reasons why this may be. David (1975) and Saloner and Shepard (1995) each show that large-scale production enables investing firms to make more intensive use of new technologies. An alternative theory rests on a large organization's ability to experiment with process changes in a single part of the production process while continuing to rely on incumbent technologies for most production needs (Hall and Khan 2003). Accounting for the number of physicians in a practice - ORGSIzEprobably picks up unobserved medical practice characteristics whose exclusion, if anything, renders the point estimates on PREPAID more conservative than they might otherwise be.

There are additional factors to control for in identifying the impact of the reimbursement model. One might expect the scope of services offered by a physician's medical practice to dictate the degree to which the practice benefits from investments in health IT, with organizations offering more types of medical services better-positioned to capitalize on the technology's coordination benefits. Therefore, the dummy variable OrGSCOPE indicates whether or not a practice offers speciality care in addition to primary care. REGION, cast as a set of binary variables, controls for urban/regional differences in adoption patterns. Finally, the models include controls for two physician-level demographic characteristics. FEMALE is a binary variable measuring the sex of the respondent, and AGE is a continuous variable reflecting the respondent's age in years at the time the survey was administered. Table 2 shows descriptive statistics for all but the binary dependent variables in Table 1. Not surprisingly, mean adoption levels rose between the two survey rounds $(p<.001)$. In both survey rounds, the stringent operationalization of the variable PREPAID ensures that a relatively small share of physicians - five percent - meet the threshold.

[Table 2 about here.]

Figure 1 expresses mean adoption levels - by year-for each of the individual health IT applications. As in the case of the aggregate intensity variable, observed adoption for each of its constituent, dichotomous components also grew between 2001 
and $2005(p<.001$ in all seven cases $) .^{3}$

[Figure 1 about here.]

I test the theory described in Section II with four linear models. I first estimate the intensity of health IT adoption - physicians' reported access to health IT - using both OLS and GLS frameworks. I then use the same two-pronged approach to model probabilities of adoption for the individual IT uses described in Table 1.

Consider first the cross-sectional estimation of ITUsE for each medical practice $i$.

$$
\begin{aligned}
\operatorname{ITUSE}_{i} & =\beta_{0}+\beta_{\mathrm{PREPAID}} \operatorname{PREPAID}_{i} \\
& +\beta_{\mathrm{CONTROLS} \mathrm{CONTROLS}_{i}}+\epsilon_{i}
\end{aligned}
$$

where $\beta_{0}$ is a constant, $\beta_{\text {Controls }}$ is a vector of slope coefficients for the control variables-OrgSize, OrgScope, Female, Age, and a set of dummy indicators for REGION, and $\epsilon_{i}$ is a zero-expectation error term. $\beta_{\text {PrePaID }}$ is the parameter of interest. According to the theory espoused above, it should be positively signed. ${ }^{4}$

Estimates of the probability of a medical practice's adoption of any of the seven individual forms of health IT are derived using probit regression. For each of the dichotomous dependent variables,

$$
\begin{aligned}
\operatorname{Pr}\left(\mathrm{IT}_{i}=1\right) & =\Phi\left(\beta_{0}+\beta_{\mathrm{PREPAID}} \operatorname{PREPAID}_{i}\right. \\
& +\beta_{\text {CONTROLS } \left.\mathrm{CONTROLS}_{i}\right)}
\end{aligned}
$$

where $\Phi$ is the cumulative normal distribution, so $\operatorname{Pr}\left(\mathrm{IT}_{i}=1\right)$ is the probability that physician $i$ 's medical practice provides its physicians access to a particular form of health IT. ${ }^{5}$

Our access to two waves of CTS data allows us to exploit the panel nature of the data using GLS (Baltagi 2005). The multilevel analog to the cross-sectional estimates

\footnotetext{
${ }^{3}$ Note that reported adoption levels are higher than in those existing studies intended to measure the adoption of integrated, interoperable EHR systems (e.g., Bower 2005, DesRoches et al. 2008, Gans et al. 2005, Jha et al. 2006).

${ }^{4}$ Since the dependent variable is actually an ordered categorical variable, an ordered probit regression would be more appropriate than OLS regressions. In all cases, results from ordered probits were qualitatively identical to OLS estimates. For ease of interpretation, I report OLS estimates.

${ }^{5}$ Though Equation 3 is estimated separately for each of the seven dummy dependent variables, Cappellari and Jenkins (2003) suggest a more complex joint estimator to capture the betweenequation covariances. These estimates yield identical estimates and significance levels while allowing us to properly test coefficients across the seven equations simultaneously.
} 
of health IT intensity, Equation 2, is

$$
\begin{aligned}
\operatorname{ITUSE}_{i t} & =\beta_{2001}+\beta_{2005}+\beta_{\mathrm{PREPAID}} \operatorname{PREPAID}_{i t} \\
& +\beta_{\text {CONTROLS }} \mathrm{CONTROLS}_{i t}+\zeta_{i}+\epsilon_{i t}
\end{aligned} .
$$

Equation 4 estimates two constant terms, one for each survey round, to ensure that point estimates can be interpreted relative to the mean for that particular round of data. Second, the multilevel model partitions the error term into two, zeroexpectation terms. $\zeta_{i}$ represents the part of the residual that is specific to each medical practice $i$ and constant across both observations of medical practice $i$ for those medical practices that appear in both the 2001 and 2005 survey waves. The second error term, $\epsilon_{i t}$, is assumed to be independent over all individual observations of each physician, $n_{i t}$, in the dataset. Likewise, Equation 3 can be recast to exploit the added information contained in panel data.

$$
\begin{aligned}
\operatorname{Pr}\left(\mathrm{IT}_{i t}=1\right) & =\Phi\left(\beta_{2001}+\beta_{2005}+\beta_{\mathrm{PREPAID}} \operatorname{PREPAID}_{i t}\right. \\
& +\beta_{\text {CONTROLS } \left.\mathrm{CONTROLS}_{i t}+\zeta_{i}\right)}
\end{aligned}
$$

As in the continuous case, the intercept has been allowed to vary between rounds, yielding $\beta_{2001}$ and $\beta_{2005}$ as opposed to a single constant term, $\beta_{0}$. The multilevel model includes a single, zero-expectation error term, $\zeta_{i}$, allowing us to relax the conditional independence assumption.

[Table 3 about here.]

Table 3 presents the first set of estimation results. All three models predict the level of health IT adoption in a primary care physician's practice as a function of the practice's financing model, controlling for size, scope, respondent demographics, and practice location. ${ }^{6}$ Models 1 and 2 are each estimates of Equation 2, the former run on the 2001 cross-section and the latter run on the 2005 cross-section. Focusing on Model $1, \hat{\beta}_{\text {PrePAID }}=1.26$ implies that net of the effects of the other covariates - most importantly, OrGSizE - those physicians based in a practice that finances care on a prepaid basis will, on average, report that their practice has invested in about one and a quarter more uses of health IT than those physicians based in practices financing

\footnotetext{
${ }^{6}$ Each model also includes a goodness-of-fit measure; however, this number has little meaning given the true, discrete nature of the dependent variable (Aldrich and Nelson 1984). Recall from Footnote 4 that OLS models offer ease of interpretation and unbiased point estimates. However, the conventional model $R^{2}$ assumes that the dependent variable can take on any value, which in this case, it cannot.
} 
care according to the traditional, fee-for-service model. The 2005 estimates, reported under Model 2, are qualitatively similar to those found for 2001. Once again, those physicians financing care on a prepaid basis are more intense adopters of health IT than those financing care in the traditional manner.

The last column in Table 3 displays the estimates of Equation 4. These rely on a GLS technique that allows us to take advantage of the larger sample size achieved by pooling the two rounds of data without violating standard assumptions regarding independence and homoscedasticity. Once again, PREPAID is positively correlated with the intensity of health IT adoption in a physician's practice. In this case, those physicians providing care on a prepaid basis report, on average, access to 1.13 more forms of IT in their offices than those physicians based in otherwise identical medical practices that finance care according to the traditional model.

\section{[Table 4 about here.]}

[Table 5 about here.]

Table 4 presents 2001 survey estimates of the seven, binary IT adoption variables. Note that in all models, the point estimate corresponding to the variable PREPAID is positive and statistically significant at conventional levels. Therefore, in all cases, net of the effects of the measured variables, those doctors whose practices finance care on a prepaid basis are more likely to report access to all seven forms of IT than those whose practices finance care on a fee-for-service basis. To be more specific, consider the estimate of $\hat{\beta}_{\mathrm{PREPAID}}=.53$ in the model predicting the adoption of IT for writing prescriptions. The point estimate implies that with the other variables held at their means, the probability that a physician reports access to e-prescribing technology is 13 percent higher under prepayment than under fee-for-service. ${ }^{7}$ The 2005 crosssectional estimates of the same model appear in Table 5 and are similar to those found for the 2001 data. That is, all seven of the technologies appear to be positively related to the use of the prepaid financing model, though two of these estimatesITCOMM and ITTREAT - fall short of statistical significance. Nonetheless, a test of the joint significance of the point estimates for PREPAID clarifies its significance as a predictor of adoption. ${ }^{8}$

\footnotetext{
${ }^{7}$ Since prepayment is operationalized as a binary variable, this calculation is obtained by differencing predicted probabilities from Equation 3 at PrePAID $=1$ and PrePAID $=0$.

${ }^{8}$ Recall from Footnote 5 that the seven probit equations for each year, while presented as independent models, were also estimated jointly to account for between-equation covariances. With respect to $\hat{\beta}_{\text {PREPAID }}$, the results are consistent with those presented here $\left(\chi^{2}=37.24, p<.0000\right)$.
} 
[Table 6 about here.]

Table 6 shows random effects probit estimates for the seven separate technologies, represented above by Equation 5. Using the pooled data, it is again clear that those physicians whose practices finance care in a prepaid fashion are more likely than doctors in otherwise similar settings to report that their practices have adopted all seven of the measured forms of health IT.

In the net, the above analyses offer strong support for the theory. In all cases, those physicians whose practices finance care on a prepaid basis were more intense adopters of health IT and more likely to adopt IT for all seven individual functions than those doctors working under a conventional, FFS reimbursement system. Most important, the effects of the financing model were detectable despite the strong effects of medical practice size.

\section{Conclusion}

The diffusion of health IT stands at the center of most prescriptions for healthcare reform in the US (e.g., Daschle, Greenberger, and Lambrew 2008, Halvorson 2007). This makes sense to the extent one believes that the transition from paper-based record-keeping to IT-driven business processes can deliver sizable efficiencies, mainly through the reallocation of healthcare resources. This paper examines the drivers of health IT adoption for primary care physicians. It finds that despite concerns about slow uptake, some physicians - those based in practices most likely to internalize the technology's benefits - are predictably more likely than others to report access to health IT - even as far back as 2001. When combined with what we know about organizations and IT - that the technology's performance benefits require additional investments on the part of would-be users, these results have implications for policymakers wishing to parlay the adoption of this technology into industry-wide performance improvements.

Earlier studies demonstrate that what were once thought to be IT-driven performance improvements were more accurately ascribed not to the technology itself, but to investments in human and organizational capital, e.g., training and the reorganization of work (e.g., Brynjolfsson and Hitt 2003, Brynjolfsson, Hitt, and Yang 2002), that must take place alongside investments in IT. Consequently, the findings in this paper do not question the potential for policy reforms to generate measurable changes in technology adoption patterns (Acemoglu and Finkelstein 2008). Rather, 
they suggest that policies aimed solely at reducing the cost of hardware and software to physicians are more likely to succeed at hastening the spread of health IT among primary care physicians than they are to actually bring about the kinds of organizational-level performance improvements that aggregate into greater economic efficiency at the industry level.

One option for policymakers would be to incentivize not just the adoption of hardware and software, but also the adoption of a prescribed set of known organizational complements. This is essentially what is behind the requirement for "meaningful use" as embodied in the HITECH Act. Thought its precise meaning has yet to be hammered out in regulations, it is likely to involve the use of IT for specific tasks, including the seven examined explicitly above. For example, it could be that in order to qualify for their full complement of incentive payments through the stimulus package, physicians must demonstrate that they are "e-prescribing" (operationalized above as ITPRESC) rather than handwriting orders for prescription drugs. This approach, though, would be imperfect relative to one that clears the way for medical practices and their physicians to realize gains from their investments in health IT. Under the approach suggested in this paper, only those practices that anticipate gains would invest in the technology, and would do so up to the point at which marginal revenues reach marginal costs. Furthermore, practices would invest in the specific technologies from which they expect to draw value and would invest in the specific complementary investments required for their particular organization to make effective use of their particular bundle of IT investments. In other words, medical practices would be the residual claimants on potentially boundless returns to health IT investments, and would have every incentive to mobilize the technology and its organizational complements towards achieving the very efficiencies intended of the technology.

An equally important set of issues concerns this link between the deployment of health IT in the form of integrated, EHR systems and measurable performance improvements, a full understanding of which requires a more-detailed analysis of incentives within managed care organizations (Gaynor, Rebitzer, and Taylor 2004). The conclusions presented here could also be strengthened and extended by demonstrating that early adopters - in this case, those adopting because they are positioned to internalize the benefits of the adoption - are both more likely to report investments in complements such as workflow redesign and more likely to report resulting performance improvements than those physicians adopting chiefly as a result of the government's financial inducements. I plan to take up this issue in subsequent studies. 


\section{References}

Acemoglu, Daron and Amy Finkelstein. 2008. "Input and Technology Choices in Regulated Industries: Evidence from the Health Care Sector." Journal of Political Economy 116 (5):837-880.

Aldrich, John H. and Forrest D. Nelson. 1984. Linear Probability, Logit, and Probit Models. Beverly Hills: Sage.

Anderson, Gerard and James R. Knickman. 2001. "Changing the Chronic Care System to Meet People's Needs." Health Affairs 20 (6):146-160.

Baltagi, Badi H. 2005. Econometric Analysis of Panel Data. 3rd ed. Chichester, NY: John Wiley.

Bates, David W. 2005. "Physicians and Ambulatory Electronic Health Records." Health Affairs $24(5): 1180-1189$.

Bower, Anthony G. 2005. The Diffusion and Value of Healthcare Information Technology. Santa Monica: RAND.

Bresnahan, Timothy F., Erik Brynjolfsson, and Lorin M. Hitt. 2002. "Information Technology, Workplace Organization, and the Demand for Skilled Labor: Firm Level Evidence." Quarterly Journal of Economics 117 (1):339-376.

Brynjolfsson, Erik and Lorin M. Hitt. 2003. "Computing Productivity: Firm-Level Evidence." Review of Economics and Statistics 85 (4):793-808.

Brynjolfsson, Erik, Lorin M. Hitt, and Shinkyu Yang. 2002. "Intangible Assets: Computers and Organizational Capital." Brookings Papers on Economic Activity 2002 (1):137-181.

Burt, Catherine W. and Jane E. Sisk. 2005. "Which Physicians and Practices are Using Electronic Medical Records?" Health Affairs 24 (5):1334-1343.

Cappellari, Lorenzo and Stephen P. Jenkins. 2003. "Multivariate Probit Regression Using Simulated Maximum Likelihood." Stata Journal 3 (3):278-294.

Center for Studying Health System Change. 2003. Community Tracking Study Physician Survey, 2000-2001. Ann Arbor: Inter-University Consortium for Political and Social Research.

- 2006. Community Tracking Study Physician Survey, 2004-2005. Ann Arbor: InterUniversity Consortium for Political and Social Research.

Chaudhry, Basit, Jerome Wang, Shinyi Wu, Margaret Maglione, Walter Mojica, Elizabeth Roth, Sally C. Morton, and Paul G. Shekelle. 2006. "Systematic Review: Impact of Health Information Technology on Quality, Efficiency, and Costs of Medical Care." Annals of Internal Medicine 144 (10):742-752.

Cutler, David M., Mark McClellan, and Joseph P. Newhouse. 2000. "How Does Managed Care Do It?" RAND Journal of Economics 31 (3):526-548.

Daschle, Tom, Scott S. Greenberger, and Jeanne M. Lambrew. 2008. Critical: What We Can Do About the Health-Care Crisis. New York: St. Martin's.

David, Paul A. 1975. "The Mechanization of Reaping in the Ante-Bellum Midwest." In Technical Choice, Innovation, and Economic Growth: Essays on American and British Experience in the Nineteenth Century, edited by Paul A. David. Cambridge: Cambridge University, 195-232. 
DesRoches, Catherine M., Eric G. Campbell, Sowmya R. Rao, Karen Donelan, Timothy G. Ferris, Ashish Jha, Rainu Kaushal, Douglas E. Levy, Sara Rosenbaum, Alexandra E. Shields, and David Blumenthal. 2008. "Electronic Health Records in Ambulatory Care - A National Survey of Physicians." New England Journal of Medicine 359 (1):50-60.

Gans, David, John Kralewski, Terry Hammons, and Bryan Dowd. 2005. "Medical Groups' Adoption of Electronic Health Records and Information Systems." Health Affairs 24 (5):1323-1333.

Garrido, Terhilda, Laura Jamieson, Yvonne Zhou, Andrew Wiesenthal, and Louise Liang. 2005. "Effect of Electronic Health Records in Ambulatory Care: Retrospective, Serial, Cross Sectional Study." British Medical Journal 330 (581).

Gaynor, Martin, James B. Rebitzer, and Lowell J. Taylor. 2004. "Physician Incentives in Health Maintenance Organizations." Journal of Political Economy 112 (4):915-931.

Griliches, Zvi. 1957. "Hybrid Corn: An Exploration in the Economics of Technological Change." Econometrica 25 (4):501-522.

Hall, Bronwyn H. and Beethika Khan. 2003. "Adoption of New Technology." In New Economy Handbook, edited by Derek C. Jones. San Diego: Elsevier, 229-249.

Halvorson, George C. 2007. Health Care Reform Now: A Prescription for Change. San Francisco: Jossey-Bass.

Halvorson, George C. and George J. Isham. 2003. Epidemic of Care: A Call for Safer, Better, and More Accountable Health Care. San Francisco: Jossey-Bass.

Hillestad, Richard, James Bigelow, Anthony Bower, Federico Girosi, Robin Meili, Richard Scoville, and Roger Taylor. 2005. "Can Electronic Medical Record Systems Transform Health Care?: Potential Health Benefits, Savings, and Costs." Health Affairs 24 (5):1103-1117.

Jha, Ashish K., Timothy G. Ferris, Karen Donelan, Catherine DesRoches, Alexandra Shields, Sara Rosenbaum, and David Blumenthal. 2006. "How Common are Electronic Health Records in the United States? A Summary of the Evidence." Health Affairs 25 (web exclusive):w496-507.

Jorgenson, Dale W. and Kevin J. Stiroh. 1999. "Information Technology and Growth." American Economic Review 89 (2):109-115.

Kaiser Family Foundation. 2007. Employee Health Benefits: 2007 Annual Survey. Washington, DC: KFF.

Mansfield, Edwin. 1961. "Technical Change and the Rate of Imitation." Econometrica 29 (4):741766.

. 1989. "The Diffusion of Industrial Robots in Japan and the United States." Research Policy $18(4): 183-192$.

McGlynn, Elizabeth A., Steven M. Asch, John Adams, Joan Keesey, Jennifer Hicks, Alison DeCristofaro, and Eve A. Kerr. 2003. "The Quality of Health Care Delivered to Adults in the United States." New England Journal of Medicine 348 (26):2635-2645.

Oliner, Stephen D. and Daniel E. Sichel. 2000. "The Resurgence of Growth in the Late 1990s: Is Information Technology the Story?" Journal of Economic Perspectives 14 (4):3-22.

Porter, Michael E. and Elizabeth Olmsted Teisberg. 2006. Redefining Health Care: Creating ValueBased Competition on Results. Boston: Harvard Business School. 
Saloner, Garth and Andrea Shepard. 1995. "Adoption of Technologies with Network Effects: An Empirical Examination of the Adoption of Automated Teller Machines." RAND Journal of Economics 26 (3):479-501.

Schoen, Cathy, Robin Osborn, Phuong Trang Huynh, Michelle Doty, Jordon Peugh, and Kinga Zapert. 2006. "On the Front Lines of Care: Primary Care Doctors' Office Systems, Experiences, and Views in Seven Countries." Health Affairs 25 (6):w555-w571.

Walker, Jan, Eric Pan, Douglas Johnston, Julia Adler-Milstein, David W. Bates, and Blackford Middleton. 2005. "The Value of Health Care Information Exchange." Health Affairs 19:webexclusive.

Wang, Samuel J., Blackford Middleton, Lisa A. Prosser, Christiana G. Bardon, Cynthia D. Spurr, Patricia J. Carchidi, Anne F. Kittler, Robert C. Goldszer, David G. Fairchild, Andrew J. Sussman, Gilad J. Kuperman, and David W. Bates. 2003. "A Cost-Benefit Analysis of Electronic Medical Records in Primary Care." American Journal of Medicine 114 (5):397-403.

Zhou, Yi Yvonne, Terhilda Garrido, Homer L. Chin, Andrew M. Wiesenthal, and Louise L. Liang. 2007. "Patient Access to an Electronic Health Record with Secure Messaging: Impact on Primary Care Utilization." American Journal of Managed Care 13 (7):418-424. 
Figure 1: Physicians' Reported Access to Seven Health IT Applications

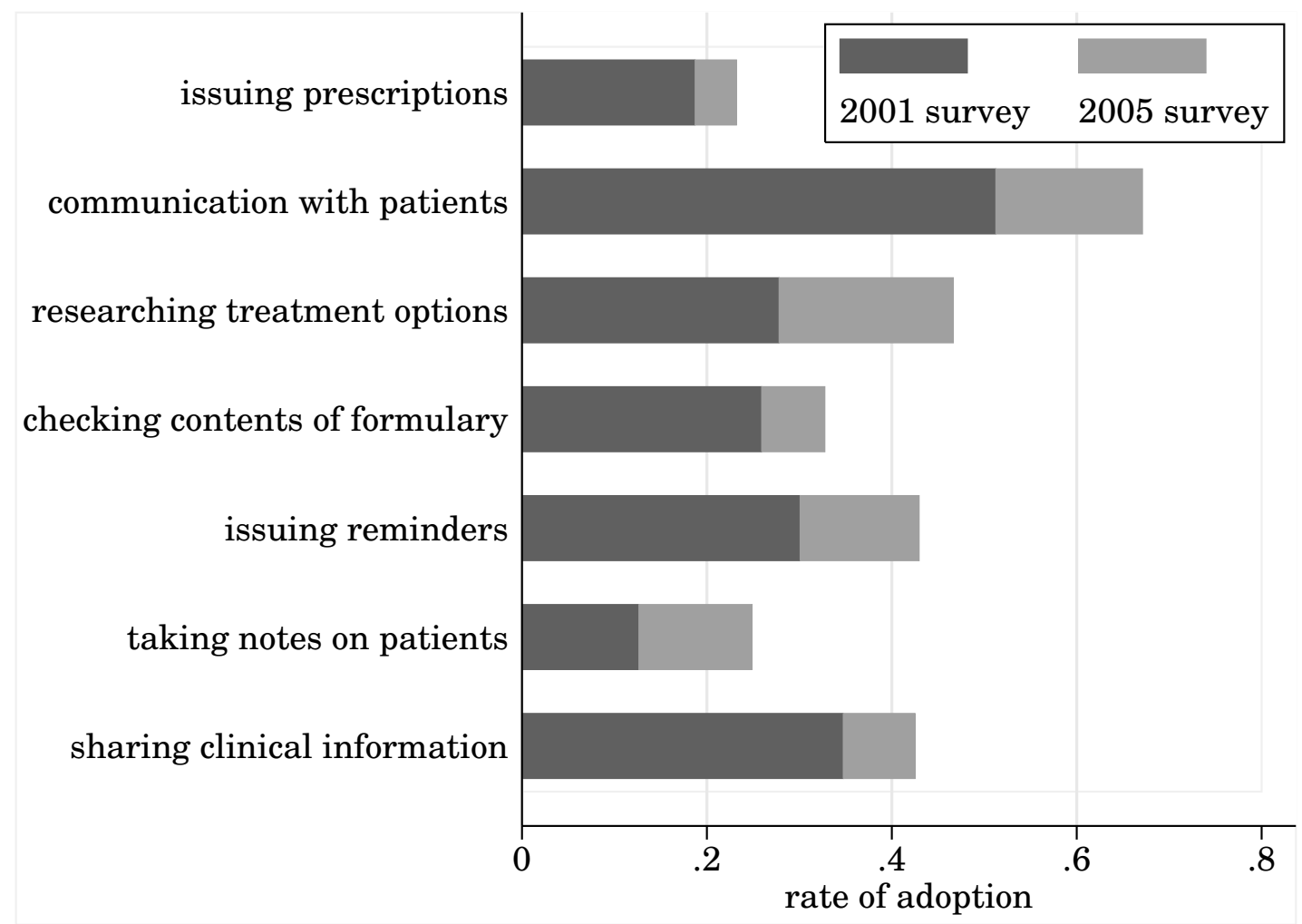

Source: Author's analysis of data from rounds 3 and 4 of the Community Tracking Study Physician Survey (Center for Studying Health System Change 2003, 2006). 
Table 1: Descriptions of Independent and Dependent Variables

\begin{tabular}{|c|c|}
\hline Variable Name & Description \& Construction \\
\hline \multicolumn{2}{|c|}{ Dependent Variables } \\
\hline ITUSE & $\begin{array}{l}\text { Intensity of IT use by the practice, constructed by summing } \\
\text { values for seven measured IT uses. (discrete, ordered variable } \\
\text { ranging from zero to seven) }\end{array}$ \\
\hline ITPRESC & ...to write prescriptions?" \\
\hline ITCOMM & $\begin{array}{l}\text { "In your practice, are computers or other forms of IT used... } \\
\text { (binary = } 1 \text { for "yes") } \\
\text {...to communicate about clinical issues with patients by } \\
\text { email?" }\end{array}$ \\
\hline ITTREAT & $\begin{array}{l}\text {...to obtain information about treatment alternatives or } \\
\text { recommended guidelines?" }\end{array}$ \\
\hline ITFORM & ...to obtain information on formularies?" \\
\hline ITREMIND & ...to generate reminders for you about preventative services?" \\
\hline ITNOTES & ...to access patient notes, medication lists, or problem lists?" \\
\hline ITCLIN & $\begin{array}{l}\text {...for clinical data and image exchanges with other } \\
\text { physicians?" }\end{array}$ \\
\hline \multicolumn{2}{|c|}{ Independent Variables } \\
\hline PREPAID & Medical practice serves as an HMO (binary = 1 for "yes") \\
\hline OrGSizE & $\begin{array}{l}\text { "How many physicians, including yourself, are in this } \\
\text { practice?" (continuous variable) }\end{array}$ \\
\hline ORGSCOPE & $\begin{array}{l}\text { Medical practice offers primary and speciality care. (binary = } \\
1 \text { for "yes") }\end{array}$ \\
\hline \multicolumn{2}{|l|}{ Control Variables } \\
\hline FEMALE & Respondent's sex (binary $=1$ for "female") \\
\hline AGE & $\begin{array}{l}\text { Respondent's age, measured as the difference between the year } \\
\text { of the survey and physician's year of birth (continuous } \\
\text { variable) }\end{array}$ \\
\hline REGION & $\begin{array}{l}\text { Regional population (categorical = } 1 \text { for "large metropolitan } \\
\text { area/population }>200,000 \text { ", } 2 \text { for "small metropolitan } \\
\text { area/population }<200,000 \text { ", and } 3 \text { for "non-metropolitan } \\
\text { area"; operationalized as dummy variables in estimated } \\
\text { models) }\end{array}$ \\
\hline
\end{tabular}

Source: Variables constructed from rounds 3 and 4 of the Community Tracking Study Physician Survey conducted by the Center for Studying Health System Change (2003, 2006). 
Table 2: Descriptive Statistics

\begin{tabular}{lclrc}
\hline & \multicolumn{2}{c}{ 2001 Survey } & \multicolumn{2}{c}{ 2005 Survey } \\
\cline { 5 - 6 } variable & mean & std. dev. & mean & std. dev. \\
\hline ITUSE & 2.0 & 1.9 & 2.8 & 2.0 \\
PREPAID & .05 & .22 & .05 & .22 \\
ORGSIZE & 36.6 & 130.4 & 43.4 & 145.5 \\
ORGSCOPE & .09 & .29 & .09 & .28 \\
FEMALE & .32 & .47 & .35 & .48 \\
AGE & 46.4 & 10.7 & 47.7 & 10.7 \\
REGION & 1.2 & .64 & 1.3 & .69 \\
& & & & \\
$n$ & 7,673 & - & 3,291 & - \\
\hline \hline
\end{tabular}

Source: Variables constructed from rounds 3 and 4 of the Community Tracking Study Physician Survey conducted by the Center for Studying Health System Change (2003, 2006). 
Table 3: Estimates of IT Adoption Levels

\begin{tabular}{|c|c|c|c|}
\hline & $\begin{array}{l}\text { Model 1: } \\
\text { OLS } \\
2001 \text { cross-section }\end{array}$ & $\begin{array}{l}\text { Model 2: } \\
\text { OLS } \\
2005 \text { cross-section }\end{array}$ & $\begin{array}{l}\text { Model 3: } \\
\text { GLS } \\
\text { pooled cross-section }\end{array}$ \\
\hline PREPAID & $\begin{array}{l}1.26^{* * *} \\
(11.60)\end{array}$ & $\begin{array}{l}.95^{* * *} \\
(5.19)\end{array}$ & $\begin{array}{l}1.13^{* * *} \\
(10.17)\end{array}$ \\
\hline OrGSizE & $\begin{array}{l}.23^{* * *} \\
(13.25)\end{array}$ & $\begin{array}{l}.38^{* * *} \\
(13.95)\end{array}$ & $\begin{array}{l}.25^{* * *} \\
(15.89)\end{array}$ \\
\hline OrGSCOPE & $\begin{array}{l}.17^{*} \\
(2.23)\end{array}$ & $\begin{array}{l}-.11 \\
(-0.85)\end{array}$ & $\begin{array}{l}.14 \\
(1.95)\end{array}$ \\
\hline FEMALE & $\begin{array}{l}-.27^{* * *} \\
(-5.37)\end{array}$ & $\begin{array}{l}-.26^{* *} \\
(-3.30)\end{array}$ & $\begin{array}{l}-.25^{* * *} \\
(-5.66)\end{array}$ \\
\hline AGE & $\begin{array}{l}-.01^{* *} \\
(-3.08)\end{array}$ & $\begin{array}{l}-.01^{* * *} \\
(-3.87)\end{array}$ & $\begin{array}{l}-.01^{* * *} \\
(-4.54)\end{array}$ \\
\hline REGION2 & $\begin{array}{l}.15 \\
(1.12)\end{array}$ & $\begin{array}{l}.36^{*} \\
(1.98)\end{array}$ & $\begin{array}{l}.22 \\
(1.95)\end{array}$ \\
\hline ReGion3 & $\begin{array}{l}.11 \\
(1.52)\end{array}$ & $\begin{array}{l}.12 \\
(1.08)\end{array}$ & $\begin{array}{l}.08 \\
(1.32)\end{array}$ \\
\hline $\begin{array}{l}R^{2} \\
n \\
\text { clusters }\end{array}$ & $\begin{array}{l}.10 \\
6,511 \\
-\end{array}$ & $\begin{array}{l}.14 \\
2,786 \\
-\end{array}$ & $\begin{array}{l}.15 \\
9,297 \\
7,471\end{array}$ \\
\hline
\end{tabular}

Key: ${ }^{*} p<.05,{ }^{* *} p<.01,{ }^{* * *} p<.001$

Notes: The dependent variable is ITUsE. Models 1 and 2 report $t$-statistics in parentheses, and Model 3 instead reports $z$-statistics. Significance tests performed using Huber-White standard errors for Model 3. Model 3 includes a dummy variable equal to unity for those observations from the 2005 survey round, allowing the (unreported) intercept to account for increases in mean IT adoption levels between 2001 and 2005. 
Table 4: Probit Regression Estimates of the Probability of IT Adoption in 2001

\begin{tabular}{|c|c|c|c|c|c|c|c|}
\hline & ITPRESC & ITСомм & ITTREAT & ITFORM & ITREMIND & ITNotes & ITCLIN \\
\hline PREPAID & $\begin{array}{l}.53^{* * *} \\
(6.08)\end{array}$ & $\begin{array}{l}.27^{* *} \\
(3.28)\end{array}$ & $\begin{array}{l}.20^{*} \\
(2.50)\end{array}$ & $\begin{array}{l}.74^{* * *} \\
(9.48)\end{array}$ & $\begin{array}{l}.55^{* * *} \\
(7.06)\end{array}$ & $\begin{array}{l}.83^{\text {*** }} \\
(10.40)\end{array}$ & $\begin{array}{l}.37^{* * *} \\
(4.67)\end{array}$ \\
\hline OrgSizE & $\begin{array}{l}.63^{* * *} \\
(4.18)\end{array}$ & $\begin{array}{l}.12^{* * *} \\
(8.81)\end{array}$ & $\begin{array}{l}.07^{* * *} \\
(5.80)\end{array}$ & $\begin{array}{l}.05^{* * *} \\
(4.20)\end{array}$ & $\begin{array}{l}.06^{* * *} \\
(4.37)\end{array}$ & $\begin{array}{l}.15^{* * *} \\
(11.70)\end{array}$ & $\begin{array}{l}.18^{* * *} \\
(14.00)\end{array}$ \\
\hline OrGSCOPE & $\begin{array}{l}.12 \\
(1.81)\end{array}$ & $\begin{array}{l}-.003 \\
(-0.05)\end{array}$ & $\begin{array}{l}-.09 \\
(-1.72)\end{array}$ & $\begin{array}{l}.12^{*} \\
(2.11)\end{array}$ & $\begin{array}{l}.04 \\
(0.65)\end{array}$ & $\begin{array}{l}.25^{* * *} \\
(4.62)\end{array}$ & $\begin{array}{l}.13^{*} \\
(2.43)\end{array}$ \\
\hline FEMALE & $\begin{array}{l}-.23^{* * *} \\
(-4.89)\end{array}$ & $\begin{array}{l}-.12^{* *} \\
(-2.80)\end{array}$ & $\begin{array}{l}-.11^{* *} \\
(-3.24)\end{array}$ & $\begin{array}{l}-.08^{*} \\
(-2.19)\end{array}$ & $\begin{array}{l}-.09^{*} \\
(-2.25)\end{array}$ & $\begin{array}{l}-.17^{* * *} \\
(-4.34)\end{array}$ & $\begin{array}{l}-.12^{* *} \\
(-3.24)\end{array}$ \\
\hline AGE & $\begin{array}{l}-.01^{* * *} \\
(-3.97)\end{array}$ & $\begin{array}{l}-.002 \\
(-0.84)\end{array}$ & $\begin{array}{l}-.01^{* * *} \\
(-7.56)\end{array}$ & $\begin{array}{l}.003 \\
(1.70)\end{array}$ & $\begin{array}{l}.003 \\
(1.84)\end{array}$ & $\begin{array}{c}-.004^{*} \\
(-2.36)\end{array}$ & $\begin{array}{l}-.003 \\
(-1.94)\end{array}$ \\
\hline REGION2 & $\begin{array}{l}-.04 \\
(0.32)\end{array}$ & $\begin{array}{l}-.12 \\
(-1.05)\end{array}$ & $\begin{array}{l}.21^{*} \\
(2.19)\end{array}$ & $\begin{array}{l}-.06 \\
(-0.54)\end{array}$ & $\begin{array}{l}.05 \\
(0.46)\end{array}$ & $\begin{array}{l}.18 \\
(1.83)\end{array}$ & $\begin{array}{l}.17 \\
(1.78)\end{array}$ \\
\hline REGION3 & $\begin{array}{l}-.03 \\
(-0.44)\end{array}$ & $\begin{array}{l}-.08 \\
(-1.34)\end{array}$ & $\begin{array}{l}.23^{* * *} \\
(4.52)\end{array}$ & $\begin{array}{l}-.04 \\
(-0.66)\end{array}$ & $\begin{array}{l}.08 \\
(1.55)\end{array}$ & $\begin{array}{l}.08 \\
(1.55)\end{array}$ & $\begin{array}{l}.01 \\
(0.20)\end{array}$ \\
\hline $\begin{array}{l}n \\
\chi^{2}\end{array}$ & $\begin{array}{l}6,547 \\
174.8 \\
\end{array}$ & $\begin{array}{l}6,544 \\
200.5\end{array}$ & $\begin{array}{l}6,542 \\
181.5 \\
\end{array}$ & $\begin{array}{l}6,537 \\
230.8 \\
\end{array}$ & $\begin{array}{l}6,540 \\
153.0 \\
\end{array}$ & $\begin{array}{l}6,546 \\
621.2 \\
\end{array}$ & $\begin{array}{l}6,540 \\
484.3 \\
\end{array}$ \\
\hline
\end{tabular}

Notes: Column names represent the dependent variable for each model. Table reports coefficients and $z$-statistics from probit models. 
Table 5: Probit Regression Estimates of the Probability of IT Adoption in 2005

\begin{tabular}{|c|c|c|c|c|c|c|c|}
\hline & ITPRESC & ITCOMм & ITTREAT & ITFORM & ITREMIND & ITNOTES & ITCLIN \\
\hline PREPAID & $\begin{array}{l}.35^{* * *} \\
(2.85)\end{array}$ & $\begin{array}{l}.24 \\
(1.89)\end{array}$ & $\begin{array}{l}.13 \\
(0.94)\end{array}$ & $\begin{array}{l}.35^{* *} \\
(2.77)\end{array}$ & $\begin{array}{l}.56^{* * *} \\
(4.48)\end{array}$ & $\begin{array}{l}.58^{* * *} \\
(4.38)\end{array}$ & $\begin{array}{l}.45^{* * *} \\
(3.37)\end{array}$ \\
\hline OrGSizE & $\begin{array}{l}.16^{* * *} \\
(8.31)\end{array}$ & $\begin{array}{l}.13^{* * *} \\
(6.94)\end{array}$ & $\begin{array}{l}.13^{* * *} \\
(6.92)\end{array}$ & $\begin{array}{l}.13^{\text {*** }} \\
(7.08)\end{array}$ & $\begin{array}{l}.11^{* * *} \\
(5.91)\end{array}$ & $\begin{array}{l}.19^{* * *} \\
(10.10)\end{array}$ & $\begin{array}{l}.23^{* * *} \\
(12.30)\end{array}$ \\
\hline OrGSCOPE & $\begin{array}{l}-.08 \\
(-0.83)\end{array}$ & $\begin{array}{l}-.16 \\
(-1.63)\end{array}$ & $\begin{array}{l}-.18 \\
(-1.90)\end{array}$ & $\begin{array}{l}-.11 \\
(-1.23)\end{array}$ & $\begin{array}{l}-.05 \\
(-0.51)\end{array}$ & $\begin{array}{l}.13 \\
(1.42)\end{array}$ & $\begin{array}{l}.05 \\
(0.51)\end{array}$ \\
\hline FEMALE & $\begin{array}{l}-.12^{*} \\
(-2.07)\end{array}$ & $\begin{array}{l}-.13^{*} \\
(-2.13)\end{array}$ & $\begin{array}{l}-.07 \\
(-1.36)\end{array}$ & $\begin{array}{l}-.03 \\
(-0.61)\end{array}$ & $\begin{array}{l}-.10 \\
(-1.85)\end{array}$ & $\begin{array}{l}-.24^{* * *} \\
(-4.38)\end{array}$ & $\begin{array}{l}-.08 \\
(-1.48)\end{array}$ \\
\hline AGE & $\begin{array}{l}-.01^{* * *} \\
(-4.79)\end{array}$ & $\begin{array}{l}-.003 \\
(-1.03)\end{array}$ & $\begin{array}{l}-.01^{* * *} \\
(-6.00)\end{array}$ & $\begin{array}{l}.0001 \\
(0.03)\end{array}$ & $\begin{array}{l}.0001 \\
(0.28)\end{array}$ & $\begin{array}{l}-.01^{* * *} \\
(-4.20)\end{array}$ & $\begin{array}{l}-.003 \\
(-1.24)\end{array}$ \\
\hline REGION2 & $\begin{array}{l}.31^{*} \\
(2.48)\end{array}$ & $\begin{array}{l}-.01 \\
(-0.05)\end{array}$ & $\begin{array}{l}.06 \\
(0.47)\end{array}$ & $\begin{array}{l}.20 \\
(1.67)\end{array}$ & $\begin{array}{l}.08 \\
(0.65)\end{array}$ & $\begin{array}{l}.24 \\
(1.94)\end{array}$ & $\begin{array}{l}.06 \\
(0.53)\end{array}$ \\
\hline REGION3 & $\begin{array}{l}.02 \\
(0.23)\end{array}$ & $\begin{array}{l}-.14 \\
(-1.64)\end{array}$ & $\begin{array}{l}.11 \\
(1.45)\end{array}$ & $\begin{array}{l}.06 \\
(0.71)\end{array}$ & $\begin{array}{l}.09 \\
(1.26)\end{array}$ & $\begin{array}{l}.12 \\
(1.66)\end{array}$ & $\begin{array}{l}.05 \\
(0.72)\end{array}$ \\
\hline $\begin{array}{l}n \\
\chi^{2} \\
\end{array}$ & $\begin{array}{l}2,814 \\
201.6 \\
\end{array}$ & $\begin{array}{l}2,811 \\
110.1 \\
\end{array}$ & $\begin{array}{l}2,811 \\
133.3\end{array}$ & $\begin{array}{l}2,805 \\
113.7\end{array}$ & $\begin{array}{l}2,804 \\
122.0\end{array}$ & $\begin{array}{l}2,812 \\
312.8\end{array}$ & $\begin{array}{l}2,809 \\
324.0\end{array}$ \\
\hline
\end{tabular}

Notes: Column names represent the dependent variable for each model. Table reports coefficients and $z$-statistics from probit models. 
Table 6: Random Effects Probit Regression Estimates of the Probability of IT Adoption

\begin{tabular}{|c|c|c|c|c|c|c|c|}
\hline & ITPRESC & ITCOмм & ITTREAT & ITFORM & ITREMIND & ITNoTES & ITCLIN \\
\hline PrePAid & $\begin{array}{l}.47^{* * *} \\
(6.32)\end{array}$ & $\begin{array}{l}.40^{* * *} \\
(3.60)\end{array}$ & $\begin{array}{l}.23^{*} \\
(2.38)\end{array}$ & $\begin{array}{l}.79^{* * *} \\
(8.77)\end{array}$ & $\begin{array}{l}.78^{* * *} \\
(7.71)\end{array}$ & $\begin{array}{l}1.18^{* * *} \\
(10.20)\end{array}$ & $\begin{array}{l}.52^{* * *} \\
(5.64)\end{array}$ \\
\hline OrGSizE & $\begin{array}{l}.11^{* * *} \\
(8.33)\end{array}$ & $\begin{array}{l}.19^{* * *} \\
(9.77)\end{array}$ & $\begin{array}{l}.12^{* * *} \\
(7.98)\end{array}$ & $\begin{array}{l}.10^{* * *} \\
(7.02)\end{array}$ & $\begin{array}{l}.10^{* * *} \\
(6.30)\end{array}$ & $\begin{array}{l}.24^{* * *} \\
(13.10)\end{array}$ & $\begin{array}{l}.24^{* * *} \\
(16.00)\end{array}$ \\
\hline OrGSCOPE & $\begin{array}{l}.06 \\
(1.12)\end{array}$ & $\begin{array}{l}-.04 \\
(-0.49)\end{array}$ & $\begin{array}{l}-.15^{*} \\
(-2.21)\end{array}$ & $\begin{array}{l}.10 \\
(1.41)\end{array}$ & $\begin{array}{l}.05 \\
(0.65)\end{array}$ & $\begin{array}{l}.36^{* * *} \\
(4.88)\end{array}$ & $\begin{array}{l}.15^{*} \\
(2.49)\end{array}$ \\
\hline Female & $\begin{array}{l}-.19^{* * *} \\
(-4.95)\end{array}$ & $\begin{array}{l}-.19^{* * *} \\
(-3.31)\end{array}$ & $\begin{array}{l}-.14^{* *} \\
(-3.15)\end{array}$ & $\begin{array}{l}-.08 \\
(-1.91)\end{array}$ & $\begin{array}{l}-.13^{* *} \\
(-2.63)\end{array}$ & $\begin{array}{l}-.28^{* * *} \\
(-5.31)\end{array}$ & $\begin{array}{l}-.14^{* * *} \\
(-3.40)\end{array}$ \\
\hline AGE & $\begin{array}{l}-.01^{* * *} \\
(-5.95)\end{array}$ & $\begin{array}{l}-.003 \\
(-1.19)\end{array}$ & $\begin{array}{l}-.02^{* * *} \\
(-8.89)\end{array}$ & $\begin{array}{l}.002 \\
(1.31)\end{array}$ & $\begin{array}{l}.004 \\
(1.70)\end{array}$ & $\begin{array}{l}-.01^{* * *} \\
(-4.02)\end{array}$ & $\begin{array}{l}-.005^{*} \\
(-2.49)\end{array}$ \\
\hline REGION2 & $\begin{array}{l}.13 \\
(1.37)\end{array}$ & $\begin{array}{l}-.13 \\
(-0.88)\end{array}$ & $\begin{array}{l}.21 \\
(1.85)\end{array}$ & $\begin{array}{l}.06 \\
(0.59)\end{array}$ & $\begin{array}{l}.08 \\
(0.67)\end{array}$ & $\begin{array}{l}.31^{*} \\
(2.50)\end{array}$ & $\begin{array}{l}.18 \\
(1.74)\end{array}$ \\
\hline ReGion3 & $\begin{array}{l}-.01 \\
(-0.26)\end{array}$ & $\begin{array}{l}-.18^{*} \\
(-2.14)\end{array}$ & $\begin{array}{l}.26^{* * *} \\
(4.11)\end{array}$ & $\begin{array}{l}-.01 \\
(-0.18)\end{array}$ & $\begin{array}{l}.11 \\
(1.67)\end{array}$ & $\begin{array}{l}.12 \\
(1.72)\end{array}$ & $\begin{array}{l}.03 \\
(0.48)\end{array}$ \\
\hline $\begin{array}{l}n \\
\text { clusters } \\
\chi^{2}\end{array}$ & $\begin{array}{l}9,361 \\
7,516 \\
510.2\end{array}$ & $\begin{array}{l}9,355 \\
7,510 \\
207.3\end{array}$ & $\begin{array}{l}9,353 \\
7,509 \\
345.5\end{array}$ & $\begin{array}{l}9,342 \\
7,503 \\
425.5\end{array}$ & $\begin{array}{l}9,344 \\
7,504 \\
222.6\end{array}$ & $\begin{array}{l}9,358 \\
7,513 \\
440.5\end{array}$ & $\begin{array}{l}9,349 \\
7,506 \\
469.3\end{array}$ \\
\hline
\end{tabular}

Key: ${ }^{*} p<.05,{ }^{* *} p<.01,{ }^{* * *} p<.001$
Notes: Column names represent the dependent variable for each model. Table reports coefficients and $z$-statistics from random effects probit models, with significance tests performed using Huber-White standard errors. All models include an intercept term and a dummy variable equal to unity for those observations from the 2005 survey round, allowing the (unreported) intercept to account for increases in mean IT adoption levels between 2001 and 2005 . 